\title{
Religion in Big History: A Neurobiological and Psychological Theory
}

\author{
Lacy Loar-Gruenler \\ MA Candidate in Creative Writing, Harvard University
}

\begin{abstract}
The most elegant and complex matter ever identified in our universe may well be the human brain, with its evolved ability to process and interpret not only our physical situation, but our existential one. For all humans ask: What is the meaning of life? Why are we here? And all humans conjecture: Surely there is something more. Although in the context of Big History we can identify elements of religion practiced as far in the past as by the stromatolites, and as recently as by our fellow primates, only humans possess the consciousness to seek definitive answers to those existential questions concerning our God or gods. In an increasingly globalized and secularized culture, is there a future for religion? Is there a place for any deity, for religion? Yes. Dramatically imagined, lovingly inclusive of all, with a shedding of institutional dogma and doctrine, cosmic religion can be found in each of us; the personal path to God or our gods lies in our evolved brains and mysterious minds.
\end{abstract}

Correspondence | Lacy Loar-Gruenler, 1a1629@g.harvard.edu

Citation | Loar-Gruenler, L. (201) Religion in Big History: A Neurobiological and Psychological Theory. Journal of Big History, III(2); 155 - 172.

DOI | http://dx.doi.org/10.22339/jbh.v3i2.3290

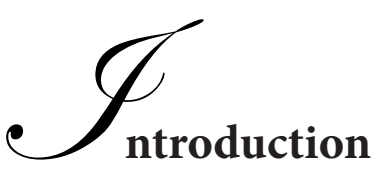

The paved road to Shanidar Cave is lined with rippling, striped Iraqi flags and modern street lights. A welcome sign in English and Arabic towers above the parking lot. Like a gaping maw cut into the verdant Bradost Mountain above the Great Zab River, the cave's mouth is arched and large, its belly a hushed and ghostly burial site, where 10 human predecessors, Neanderthals, were laid to rest about 60,000 years ago. ${ }^{1}$ One of them, with his prominent brow, bewhiskered face and hirsute body, apparently was crushed in a rockslide. Had he been crippled from his misfortune, anthropologists tell us that others would have cared for him. At his death, he was interred in a crude ritual that includes mounding stones carved to points on top of his grave, and then building a roaring fire nearby. ${ }^{2}$ Perhaps his tribe was attempting to weight his spirit to the Earth or arm him with arrow tips for protection in the next world, a grand gesture of metaphysical hope; perhaps the angry flames were meant to keep demons at bay.

Neanderthal burial rituals tell us two things, according to neurobiologist Andrew Newberg, "First, they possessed sufficient brain power to comprehend the inescapable finality of physical death; and second, they had already found a way to defeat or cope with it, at least conceptually." ${ }^{3}$

Relics of ritual, proto-religious behavior, including animal sacrifices and interment with weapons, clothing and food, have been unearthed from Neanderthal gravesites scattered over Europe, Asia and the Middle East, dating to as long ago as 200,000 years. ${ }^{4}$

Even longer ago, several hundred thousand years, the genus Homo emerged in the form of Homo erectus, the first human to walk upright, and the first thought to perceive a spiritual reality beyond material forces, with its evolved brain that contained the complex neural structures needed for language function, including causal and antinomic thought needed for myth-making, which is critical in the evolution of human morality and religion. ${ }^{5}$

And much, much longer ago, in the Archean period, about 3.5 billion years ago, more than 10 billion years after the Big Bang, complex life began to emerge into an atmosphere thick with noxious sulfur and hydrochloric acid, but devoid of oxygen. For two billion years before, only simple bacterial organisms called cyanobacteria 
made their home on Earth, existing on hydrogen in water molecules, and excreting oxygen, the Goldilocks condition needed to welcome photosynthesizing stromatolites, a living rock that may be thought of as the emergence of moral behavior, a precursor to religion. Anthropologist Ruth Benedict points out the common thread of religious practice in all cultures: "religion is a technique for success," because it addresses values and answers questions that are critical for our existence. ${ }^{6}$ Fundamentally, moral behavior is inextricably based on rules of peaceful cooperation. From a Big History vantage point, these moral rules can be traced to the early stromatolites, clinging together on little rocks in shallow seas to improve their survival chances. ${ }^{7}$

And it is survival that motivates all organisms to negotiate their environments using their internal, organic bundles of neurons to sort, process, and make sense of the bombardment of sensory data that, if correctly interpreted, means life for a little longer. Brains, and the neural systems on which they rely, have through thousands of years of genetic fine tuning become increasingly complex, allowing organisms to understand and react to their environments in more efficient ways. "The billowing complexity that characterized the evolution of neurological systems reaches its fullest point so far in the elegant engineering of the human brain," says Newberg. ${ }^{8}$

The hominid(ae) family lines leading to modern humans experienced an incredible expansion of brain size, from $600 \mathrm{gm}$ in Homo habilis, who is presumed to have walked erect and made primitive tools, although without any opposable thumbs, to 1500 gm in Homo sapiens Neanderthalensis. "In hominid species, therefore, it looks as though there was a very special kind of selection pressure towards larger brains, but it should be emphasized that this selection pressure began to operate at the early stages of hominid evolution, long before the emergence of Homo sapiens," says psychologist Stephen Walker. ${ }^{9}$ Thus, the evolution of hominids' brain size culminates in the complex brains of modern humans, allowing us to interpret reality, including contemplation of forces beyond our perceived world, and change our behavior to adapt instead of waiting for genetic variation. ${ }^{10}$ As William Grassie puts it, "It is worth stopping a moment to reflect that the most complicated object in the known universe is sitting right here between our ears." ${ }^{11}$ Specifically, as species evolved, neural strings in the brain evolved too, becoming longer, looping bundles that formed neural networks, which grouped into highly specialized areas to allow even more sophisticated sensory perception, processing, and adaptation after connecting circuits developed. The cerebral, or neo cortex, the most recent addition to the heft of the hominid brain, allows humans to employ higher cognitive functions in the creation of language and culture, including religion. ${ }^{12}$ And religious emotion in humans, once an elusive concept rooted in survival through cooperation, fear, superstition, the desire to connect with dead ancestors, and guilt, has evolved too. Today, it can be scientifically measured through brain science.

A subset of the brain, because it is wholly dependent on it, is the mind, which is much like an iceberg with consciousness visible and unconscious drives hidden beneath the surface. The heightened complexity of the brain eventually led to its ability to perceive itself, a phenomenon neurology can not explain since a nonmaterial essence is found arising from the biological functions of the material brain. "Our hypothesis specifically holds that 'mind' and 'brain' are two views of the same reality - mind is how the brain experiences its own functioning, and brain provides the structure of mind." 13 The mind, then, is a system of computation that developed as Charles Darwin predicted, by natural selection, originally to process sensory perception and regulate body functions, but also to solve the problems our hunter-gatherer ancestors faced from the perils of nature. ${ }^{14}$ In reverse-engineering our mind, figuring out what it was meant to do, we find answers to our biggest questions in psychology, as well as in biology, studying how the brain works.

Thus, the human cranium is a jewel case, protecting evolution's priceless gem of many facets, allowing 
us to perceive reality and to enter altered states of consciousness to understand it. For surely there is something 'more' than Sartrean Existentialism. We as humans have the capacity to seek spiritual reality that lies beyond rote processing of sensory input. Our communal wish is to understand why we are here, to know how we can overcome our fear of a baffling world and of death, and to explain what makes each of us part of the whole of the universe. In other words, in a spiritual realm, we seek our god or gods for answers to how we can make order out of chaos. Grassie says, "To talk of spirituality, then, is to affirm that there is an allencompassing realm, an invisible reality that somehow transcends and sustains human life, consciousness, and values, indeed the entire universe."15 Our hurdle is that what we perceive as reality is only a rendition of reality that is created in the brain, subjectively ordered by genetics and interpreted with influence by the specific cultures in which we must live. The various religious practices are the bedrock of culture, and culture the form of religion. ${ }^{16}$ But myriad religious beliefs have not been satisfactory, because different cultures, different belief systems, our own experiences, are pitted against each other. Waning participation and radical incarnations show us that we must rise above the divisiveness of competing institutional religions. The answers appear to be in each of us. "Neurology makes it clear: There's no other way for God to get into your head except through the brain's neural pathways. Even if there were a soul through which God could communicate, it would have little cognitive meaning to us without a brain," Newberg says. ${ }^{17}$ And psychology makes it clear: A spiritual sensibility has always resided in humans, evolved within our brains. It can be found in every mind that seeks it. "This something common, this something which is left over after we peel away all the localism, all the accidents of particular languages or particular philosophies, all the ethnocentric phrasings, all those elements which are not common, we may call the 'core-religious experience' or the 'transcendent experience," says psychologist Abraham Maslow. ${ }^{18}$

And so, the inextricably evolved human brain and mind gift us with the ability to contemplate our connectedness to something more, to something transcendent. In the words of philosopher and psychologist William James, "beyond each man and... continuous with him there exists a larger power which is friendly to him and to his ideals ... (a power) both other and larger than our conscious selves." 19 This is the gift found by seeking our inner numinosity. It is built from specific religious components such as cooperation, altruism, empathy, and care for others, instead of from fear and guilt, which is often prescribed by institutional religion. The seeds of numinosity began evolving in the brains of living organisms as long ago as the stromatolites, to ultimately become an intrinsic morality and spirituality in the most complex animals, primates, and specifically humans. It is this gift, along with a reimagined future for religion without the restraints of dogma, fear, and guilt, that we shall now explore.

\section{Religious Components Within Us: Moral Behavior}

Specific components that favor survival evolved within life forms as building blocks for later moral behavior, which is the foundation of religion. Just as the stromatolites practiced peaceful cooperation to survive, later primitive organisms found that group cooperation, called eusociality, contributed to adaptive reproduction. Theologian Ted Peters explains that eusociality involves not only cooperation, but in colonies of insects, crustaceans and mammals, it involves parental care for the group's young, a division of labor, and deference for breeding to the group's dominant caste. ${ }^{20}$ Survival of the fittest is best accomplished by interdependence and interaction. Beginning with eukaryotic organisms, "life did not take over the globe by combat, but by networking. Life forms multiplied and complexified by co-opting others, not just by killing them," says biologist Lynn Margolis. $^{21}$

In tracing the evolution of religious components, we are led to the Ethiopian Afar Triangle, where 
archeologists in 1994 discovered the world's oldest hominin (a sub-family of hominid) bones ever unearthed, a 4 -foot tall female, dated at 4.4 million years ago. She is categorized as the species Ardipithecus ramidus, which translates to 'ground floor' in the Afar language. Anthropologists named her Ardi. What we know about Ardi is that she lived in wooded areas and was both bipedal and able to climb along branches on all fours. She and the other specimens found nearby, both male and female, had small canine teeth. Scientists attribute to Ardi's species more and earlier-than-supposed pair bonding with males. The small canine teeth indicate reduced male conflict over females, as our last common ancestor appears to have been evolving attributes marked by increasing civility and socialization.

The genus Homo began to appear about 2.5 million years ago, when $H$. rudolfensis, $H$. habilis, and $H$. ergaster began to evolve larger brains, shorter arms, and smaller teeth, although they were still apelike in many ways. Fossils found indicate that early Homo species employed crude stone tools and were bipedal. About 2 million years ago, various Homo species had abandoned the trees for open landscapes and larger groups, with communication still limited to apelike vocalizations and gestures to convey messages to others.

The decidedly more human-like Homo erectus emerged about 1.8 to 1.7 million years ago, displaying a brain about $70 \%$ the size of modern humans' and a body almost the same size. About 75 skeletons have been discovered all over the world, although not in the Americas. This species no longer swung in trees and is known to have acquired balance through the emergence of human-like canals in the inner ear, allowing $H$. erectus to run, jump, and dance, which are important rituals for socialization and religious ceremonies. A narrower birth canal forced females to give birth to offspring with smaller heads, and thus with brains not fully developed, meaning newborns needed extended parental care until maturity. Since males began protecting the mothers and their offspring to better ensure survival of the helpless newborns, pair bonding became more prevalent. $H$. erectus is thought to have been the first ancestor to harness fire for cooking and warmth, which increased social interaction, including through language using simple nouns and verbs, and in the fashioning of advanced tools. ${ }^{22}$

\section{Aggression, Free Riders, and Altruism}

As a counterpoint to cooperation, our primitive ancestors also displayed aggression towards members of other and of the same species, a trait that is evident in modern humans. Many of the rituals associated with aggressive behavior include appeasing gestures of submission, which were meant to diffuse competition before the death of a losing actor. All vertebrate species can act aggressively, it is innate in lower species, but humans have made particular use of aggression, for instance, in their ability to make and employ weapons in war. Physiologist Konrad Lorenz makes the counterpoint that humans, with higher cognitive development, are also uniquely able to control their emotions and channel them toward altruistic pursuits; aggression thus modified by imagination and inference. ${ }^{23}$ And if we look to other primates, particularly chimpanzees and bonobos, with whom we share about 98.8 percent of our DNA, we find strikingly similar brains that reflect the ability in primates other than humans to behave sensitively toward others. Once thought only a human purview, the spindle cell, which affects self-control, empathy, and self-awareness, has been found in the brains of apes, including bonobos. "Areas involved in the perception of another's distress, such as the amygdala and anterior insula, are enlarged in the bonobo. Its brain also contains well-developed pathways to control aggressive impulses," according to primatologist Frans de Waal. ${ }^{24}$

Sigmund Freud in Totem and Taboo shares his theory of the early Homo species and its propensity for aggression, early myths, and for symbols. In this protoculture, nomadic foragers, probably Homo erectus living in small family bands, are ruled by a brutal, 
dominant male, who mates indiscriminately, including with his daughters, and banishes, castrates, or kills any male, including his sons, who would challenge his authority. Eventually, banished sons decide as a group to end the violence and incest by attacking the father, killing him, and cannibalizing him with the belief that his strength and power would live on in them. But the human emotions of guilt and shame also arise in the murderous sons. To atone, they recreate the event in symbolic form with periodic feasts in which a totem, a sacred animal as a symbol of the slain father, is sacrificed and eaten to commemorate the father's power. Murder is outlawed, along with incest, the two taboos that are the subject of Freud's Oedipal complex. Freud believes that the killing of the father is humanity's original sin, and that the act and subsequent atonement by the sons is the beginning of morality, as a necessity for living in society and for making amends, and of religion, as a construct for handling the sense of guilt and remorse, and for reconciliation with the father by subsequently vowing obedience. ${ }^{25}$

Freud's theory is reiterated in part by cultural anthropologist Christopher Boehm, whose behavioral reconstruction of primates' common ancestor finds dominant alpha males in charge, and subordinates who dislike their status. "In fact, in all four of these living apes (gorillas, chimpanzees, bonobos, and humans), rebellious subordinates can form counterdominant coalitions."26 Ted Peters asks if a selfish gene is responsible for human violence, to which he is answered 'yes'. "Of all our human hallmarks...the one that has been derived most straightforwardly from animal precursors is genocide." 27 Although a selfish gene may aid some primates in eliminating the enemy as competition for survival, since genocide is still practiced today, Peters points out that humans also engage in gratuitous violence often spurred by memetic desire and not by survival of the fittest. Humans also love their neighbors and perform altruistic acts. "To date, sociobiology has failed to account for the most noble and enviable virtues of the human race." 28 Despite humans' propensity toward violence, our common ancestor may have experienced shame for breaking rules, including for violent acts, a preadaptation of the conscience in modern humans. In further support of Freud's theory, sacrifice, according to theologian Robert Bellah, is a crucial element in hierarchal authority found in ancient societies. In ancient Greece, for example, participation in a sacrificial meal "became a central and defining ritual of the polis itself, an early example of there being no distinction between religion and politics. ${ }^{29}$

Elements of Freud's concept continue today in the Christian ritual of Communion, in which Christ's body and blood are consumed in symbolic form, and of Christian adherence to moral law such as the Ten Commandments. It may even continue in its original form in Papua, New Guinea, where natives have been sharing cooked humans in a ritual to gain the victim's power, as noted in an 1846 missionary's account. "The Somosomo people were fed with human flesh during their stay at Bau, they being on a visit at that time; and some of the chiefs of other towns, when bringing their food, carried a cooked human being on one shoulder, and a pig on the other; but they always preferred the 'long pig,' as they call a man when baked." ${ }^{0}$ Nobody since 2011 has reported that cannibalism is still occurring in New Guinea. Perhaps it is not. Or perhaps it is, and that is why nobody has reported.

Despite being capable of virtuous acts, humans have struggled with curtailing their murderous aggression, as well as with forms of cheating, since the emergence of the genus Homo. The beginning of a moral code, one tenet on which religion rests, is much older than institutional religion, and is entrenched in us through thousands of years of natural selection. Newberg defines it as "a combination of learned beliefs, neurological development, and peer-group consensus. But something else is needed to maintain moral beliefs, and that is social order." ${ }^{31}$ Early huntergatherers learned just that as they devised an effective cure to contend with aggressors or cheating free riders who disrupt peaceful cooperation and altruistic behavior, which eventually disrupts the individual's 
and the group's ability to survive. For this reason, foraging bands kept close watch for social deviance in group members, who were punished in a variety of ways, from ostracism to capital punishment. Writes anthropologist Christopher Boehm, "Thus, we must ask whether traits that make for seriously antisocial free riding - free riding that invites severe punishment - may often be far more costly to the would-be free rider than are the costs of being generous for the altruists they are genetically competing with. If so, for humans alone we have a possible definitive solution for the genetic free-rider problem."32 Free-riders who are ostracized suffer the loss of basic human needs, which can compel them to think twice before cheating, since these needs can only be fulfilled by and through other humans forming a society. "The need for community (belongingness, contact with others) is itself a human need. Loneliness, isolation, rejection by the group these are not only painful but pathogenic as well," says psychologist Abraham Maslow. ${ }^{33}$

Moral behavior is the internalized basis for prosocial activity and is codified into commandments or laws by all religions. It springs from empathy, the ability to connect emotionally with how another feels, and from altruism, aiding another who needs help preferably without thought about reciprocity. ${ }^{34}$ It is tied to the conscience, and is an innate trait, something the evolutionary scientist Charles Darwin concludes in his 1871 pronouncement, "Any animal whatever, endowed with well-marked social instincts, the parental and filial affections being here included, would inevitably acquire a moral sense or conscience as soon as its intellectual powers had become as well developed, or nearly as well developed, as in man." ${ }^{35}$ Thus, our moral life would be a miserable quagmire of shame and fear of punishment without innate altruistic traits. Boehm says, "Sensing the needs of others can lead us to spontaneously respond with generosity, and this, along with counting on future benefits form the generosity of others, makes the system work." 36 There also is a correlation between psychological health and altruistic behavior. As prosocial animals, humans want to help others because it feels good. "An examination of emotionally healthy persons shows that when they behave unselfishly, this behavior tends to be a phenomenon of personal abundance stemming from relative basic gratification. It comes out of inner riches rather than inner poverty. The same kind of examination of neurotic persons will show that their selfish behavior is typically a phenomenon of basic deprivation involving threat, insecurity, and inner poverty," says Maslow. ${ }^{37}$

William Grassie does caution us that the other side of altruism hinges on our tendency to demonize those outside of our own groups, when being wronged by an outsider often unleashes outsized emotional outrage, harnessed for evil, for instance, when soldiers will kill their perceived enemies. "The dark side of altruistic self-sacrifice, the immoral side of morality, may yet prove to be our species's evolutionary downfall." ${ }^{38}$

\section{Nature, Reality, and Mind Over Matter}

Our hunter-gatherer ancestors, after the invention of farming about 10,000 years ago, were free to use their larger brains for more cerebral pursuits, such as writing and thinking more abstractly in terms of a differentiated consciousness between the objective and the subjective. About $500 \mathrm{BCE}$, categorized as the Axial Age by Karl Jaspers, many diverse cultures that believed misfortune could be thwarted by ritual and sacrifice revised their belief systems to embrace philosophical and religious ideas that promoted altruism and promised spiritual transcendence. During the Axial Age, economic efficiency meant more energy which fueled "larger cities, a scholarly and priestly class, and a reorientation of priorities from short-term survival to long-term harmony."39

Differentiated consciousness supports dualism that is one critical view of nature, in which the body and the soul are separate realms. "What people experience in the physical world is temporal, ephemeral, corruptible, and subject to death. Beyond the shadow of the physical world is the transcendent realm of spirit, which is eternal, immutable, incorruptible, and life-giving ... 
to be attuned to the realm of spiritual light is to live in the truth, to live in the realm of God," writes Peters. ${ }^{40}$ This discovery of a transcendent reality in human consciousness is called the axial breakthrough, and the axial worldview is often called perennial philosophy. Although more recent models of nature are mechanistic and contingent on rationality, scientific empiricism, and relativism, dualism is especially appealing because it bestows both sacredness and order to the universe.

Psychologist Carl Jung believes that duality in each of us, and in nature, is needed for a functioning universe. "The unconscious is not just evil by nature, it is also the source of the highest good: not only dark but also light, not only bestial, semi-human, and demonic but superhuman, spiritual, and, in the classical sense of the word, 'divine."'41 And in advocating for the idea that we are all one with nature, Islamic philosopher Seyyed Nasr champions "the resacralization of nature, not in the sense of bestowing sacredness upon nature... but of lifting aside the veils of ignorance and pride that have hidden the sacredness of nature from the view of a whole segment of humanity." 42

Duality then, is a reality made up of matter and substance, an objective reality that we can perceive, and a subjective reality in our minds, in which concepts and conscience reside, along with who we deem ourselves to be, and some essence that connects us to something more. And it is to neuroscience and psychology that we now turn to find that subjective reality, that 'something more.' In the words of geneticist Theodosius Dobzhansky, "Man's conscience, the existence of life, and indeed, of the universe itself, are all parts of the mysterium tremendum." ${ }^{43}$ The term mysterium tremedum was coined by philosopher and theologian Rudolph Otto, and discussed in his book, The Idea of the Holy. At the heart of the mystery is the experience he calls numinous. Otto explains numinosity this way:

"The feeling of it may at times come sweeping like a gentle tide pervading the mind with a tranquil mood of deepest worship. It may pass over into a more set and lasting attitude of the soul, continuing, as it were, thrillingly vibrant and resonant, until at last it dies away, and the soul resumes its "profane," non-religious mood of everyday experience ... It has its crude, barbaric antecedents and early manifestations, and again it may be developed into something beautiful and pure and glorious. It may become the hushed, trembling, and speechless humility of the creature in the presence of-whom or what? In the presence of that which is a Mystery inexpressible and above all creatures." $^{4}$

Christian mystic and theologian, Augustine of Hippo, addresses the issue in his autobiography, The Confessions, in which he recognizes the duality in the numinous, with its connections to something we can not fully comprehend, but which fills us with awe and wonder, as well as with a numbing chilliness. Augustine's 'wholly other' is his perception of being connected to God as an alternate but ultimate reality. He writes, "What is that which gleams through me and smites my heart without wounding it? I am both a-shudder and a-glow. A-shudder in so far as I am unlike it, a-glow in so far as I am like it." ${ }^{45}$

Numinosity is called many things by many thinkers. Freud calls it the oceanic feeling; Jung maintains Otto's term numinosum; Maslow calls it the peak experience; Albert Einstein the cosmic religious feeling; Ted Peters the beyond sensibility; Mircea Eliade the wholly other; and in Buddhism it is called nirvana.

\section{Jung's Inherited Archetypes}

Numinosum is involuntary, and seizes its subjects, controlling them in a peculiar alteration of consciousness. It is the job of religion to consider this state, but Carl Jung makes a clear distinction between religion and creed. "Religion appears to me to be a peculiar attitude of the human mind, which could be formulated in accordance with the original use of the term "religio," that is, a careful consideration and observation of certain dynamic factors, understood to be 'powers' spirits demons, gods, laws, ideas, ideals or whatever name man has given to such factors as he has found in his world powerful, dangerous or 
helpful enough to be taken into careful consideration, or grand, beautiful and meaningful enough to be devoutly adored and loved." 46 Thus, religion is the experience brought about by numinosum, but institutional religion is not the same thing; it is dogma and creed, merely codified forms of the numinous experience. These forms coagulate into static rituals and unbending institutions. Thus, numinosity is not reserved for extreme, devout religious practitioners, or for saints and mystics. It can be reached by all of us through prayer, meditation, yoga, chanting, ritual dancing, and even through a 'devout' passion for cultural elements such as nature, science, and art. And it can, of course, be reached by searching for God, as Newberg has recorded in the brain waves of Buddhist monks and Catholic nuns. Reaching numinosity, or nirvana, however, is a long and difficult journey. "We have not all achieved nirvana and are unlikely to do so. It is perhaps the questing after enlightenment or God, rather than the actual achievement of enlightenment or finding God, that is the most wholesome and transformative aspect of religion. In that quest, there is no reason not to invite science, including the neurosciences, along for the ride," says Grassie. ${ }^{47}$

Jung does not claim that God exists, only that an archetypal image of Him exists; God is real in the minds of believers. As are the myths associated with the world's religions, such as the virgin birth, in which Jesus, Mohammed, Perseus, and Buddha were all born of virgins. Jung claims that he was never trying to prove that the virgin birth was a true occurrence. What is provably real is that the mind works in a certain way that allows many people to believe that the virgin birth occurred. "We live in a modern setting, where the ultimate things are doubtful, where there is a prehistory of enormous extension, and where people are fully aware of the fact that if there is any numinous experience at all, it is the experience of the psyche. We can no longer imagine an empyrean world revolving round the throne of God, and we would not dream of seeking for Him somewhere behind the galactic systems. But the human soul seems to harbor mysteries, since to an empiricist all religious experience boils down to a peculiar condition of the mind." 48

In a prescient statement made 80 years before Newberg confirmed it with neurobiological experiments, Jung introduced us to archetypes that explain his certainty that biology and the brain, which powers the mind, were behind religious thought. He had witnessed countless of his patients express religious ideas that had prevailed for the past 2,000 years. "Such a continuity can only exist if we assume a certain unconscious condition carried on by biological inheritance. The inherited quality, I fancy, must be something like a possibility of regenerating the same or at least similar ideas. I have called the possibility 'archetype,' which means a mental precondition and a characteristic of the cerebral function." ${ }^{49}$

\section{Freud's Revision}

Soon after the publication of his book, The Future of an Illusion in 1927, Sigmund Freud received a letter from his friend, Romain Rolland, a French novelist and mystic who told Freud that he agreed with his assessment of religion as an illusion, but that Freud missed the point when he did not acknowledge the true meaning of religious sentiment. Freud writes: "This, he (Rolland) says consists in a peculiar feeling, which he himself is never without, which he finds confirmed by many others, and which he may suppose is present in million of people. It is a feeling which he would like to call a sensation of 'eternity', a feeling as of something limitless, unbounded - as it were, 'oceanic"'

Freud never found such a feeling in himself, but does not dispute that for others, it is a subjective and indissoluble bond with the universe. His theory comes from psychoanalysis, in which the ego of a mature adult, with its clear delineation of self and notself, has retained vestiges of an infantile state before the ego recognizes this delineation, when the world and the child are one. As the child matures, the ego separates from the mass of worldly sensations that are unpleasant to it, until the mature ego can reject 
and remove whatever is a source of displeasure. It is a pathology of blurred egoism, some remnant of the ego and the world as one, that comprises the oceanic feeling for Freud..$^{50}$

In his later writings, Freud revises his view of humans as primarily ruled by a destructive or death instinct found in an aggressive and barbaric id, which we are constantly under pressure to contain through the superego (inner guilt), when we really do not wish to. Perhaps if he had lived, Freud would have reimagined his oceanic feeling as one governed by his later theory of Eros, the love instinct, that is tasked with "combining single human individuals, and after that families, then races, peoples and nations, into one great unity, the unity of mankind, making more than one into one." ${ }^{51}$ Freud calls his revised dualistic theory of destruction and construction a cosmic struggle of opposites, the battle of the giants within us between love and hate, and it would seem reasonable to assign the oceanic feeling to Eros as a cosmic principle of creation, expansion, unification, and preservation, our connection to something greater. ${ }^{52}$ In his final years, even the maestro of the mind reevaluates what life, death, and eternity mean to humans.

\section{Maslow's Personal Religion}

In Abraham Maslow's hierarchy of needs, the beginning of humanistic psychology, he places the numinous experience at the top of the pyramid, as a state that could not occur until the basic physiological, safety, love and belonging, and esteem needs were met. Few people were thought to be able to reach this pinnacle; after all, we must live in and maneuver the mundane world each day, but Maslow believes it is attainable by all who work hard for it. Self-actualization is the state of knowing and being, in which all prejudices and fears fall away, and a true sense of inner morality, psychological health, and contentedness overtakes us. Part of this process is the numinous, or as Maslow calls it, the peak experience.

Although the numinous began as a concept reserved for religious contemplation, predominantly by mystics and the prophets of all high religions who sought to communicate their revelations to the masses, Maslow's theory broadens the concept to include all of us, over all time, who have asked and will ask the questions concerning our meaning and existence. Maslow regards institutional religion as at odds with the peak experience because the hierarchy is comprised of non-peakers who over history have presented intellectually unacceptable answers to existential questions. "The religious questions themselves-and religious quests, the religious yearnings, the religious needs themselves-are rooted deep in human nature, and can be studied, described, examined in a scientific way, and the churches were trying to answer perfectly sound human questions. As a matter of fact, contemporary existential and humanistic psychologies would probably consider a person sick or abnormal in an existential way if he were not concerned with these 'religious' questions." ${ }^{53}$

The peak experience is found in both theistic or supernatural, and non-theistic contexts; it is unique to each person. Thus, "each peaker discovers, develops, and retains his own religion." ${ }^{4}$

\section{Numinosity and Brain Science}

And so, the large and complex brain in our early ancestors processed the responses to sociability issues, memory, imagination, but especially to fear and imminent danger, in which the limbic structures trigger the autonomic system. But because of the cerebral cortex, more developed in humans than in any other animals, humans began to think abstractly, sensing danger before it is imminent, and resolving it through inventive means, such as tool-making, and banding together, for both safety and hunting. Our ancestors also used this abstract thinking to envision a better future for all. They enacted laws, shaped civilizations, discovered science and technology, created art and music, and adopted religions to answer existential questions. "All of the lofty reaches to which human achievement has carried us - from the first spearhead to the latest innovation in heart transplant surgery-can 
be traced to the mind's need to reduce the intolerable anxiety that is the brain's way of warning us that we are not safe." ${ }^{55}$ These high-level thought processes are called the cognitive operators. This adaptive process was so successful that evolution provided the human brain with a biological compulsion to use it, which is called the cognitive imperative, which drives us to make sense of the world through by using our brains to analyze reality. Our ontological yearning inspired by the cognitive imperative led to our ancestors dealing with their anxieties about death and meaning by creating stories and ultimately myths to organize their perceptions. "Storytelling brings into play all of the cognitive and emotional circuitry evolved to deal with real experience," says noted biologist E.O. Wilson." ${ }^{56}$

\section{Myth}

From storytelling, myths evolved, most of which are structured to appeal to the cognitive imperative. An existential concern is identified, and the concern is framed in dualistic terms, between dueling opposites, and finally, that concern is resolved, often by gods who relieve the brain of its existential concerns, causing us to feel relieved and happy. For example, in Christian mythology, an existential dualism is identified by Augustine, naming heaven as the city of God and Earth as the city of man. Humans are sinners, so heaven is unattainable to them, until God benevolently sacrifices his only son Jesus who, with his death and resurrection, provides eternal salvation to the city of man. Other gods and chosen men have patched the rift between heaven and earth, including the Egyptian Osiris, the Greek Dionysus, the Syrian Adonis, and the Mesopotamian Tammuz. ${ }^{57}$

The creation of myth is most heavily influenced by two cognitive operators, the causal operator, which allows our brains to link an event to an abstract cause, and the binary operator, which allows our brains to define the world in the dualities about which Carl Jung wrote..$^{58}$ Jung's imperative that duality creates order in the universe is an evolutionary truism linked to the binary operator, which does not just identify opposites, it has evolved to create them as a way for us to conceptualize space and time into manageable units. Newberg theorizes that Homo erectus, our ancestor of several hundred thousand years ago, sported a brain complex enough to contain the neural network for language and speech, including a developed parietal lobe used to power causal and antinomic thinking necessary for myth-making. Many of these myths then, have been inherited throughout time. Jung believes them to be symbolic expressions of archetypes: inherited ideas and thoughts that are universal, and that exist deep within every human mind. ${ }^{59}$

\section{Ritual}

Along with myths, primitive humans who were bonded by kinship in tribes or clans also practiced rituals to gain favor with the deities they worshipped, as well as for many pro-social reasons, such as control of the tribe, its hierarchy and its power structure. ${ }^{60}$ Long thought to be a cultural phenomenon, neurobiologist Eugene d'Aquili in the 1970s proposed that human ritual has biological roots, as well as evolutionary roots in common with animal ritual, both of which were used as forms of communication, sending messages of friendship, greetings, submission, and intent to mate. ${ }^{61}$ Ritual is common in our everyday lives, for instance, the common handshake, but it is the use of ritual in transcendence on which we shall focus.

Our transcendence into a something larger than we are is the primary goal of ritualized behavior. Religious transcendence uses ritual to unite worshipers to a higher spiritual reality, one's God or gods. Historians tell us that religious rituals have existed in every human culture in many different forms in our quest to understand the mystery of something beyond our objective reality. Carl Jung claims that this quest is the innate human search for a soul because the human psyche has always yearned to fulfill deep spiritual needs. "All creativeness in the realm of the spirit as well as every psychic advance of man arises from a state of mental suffering, and it is spiritual stagnation, psychic sterility, which causes this state. It is only the 
meaningful that sets us free." ${ }^{2}$ Medieval mystic Saint Teresa of Avila describes the transcendent experience as a journey of contemplation in our search for God within ourselves. There is "a magnificent castle inside our own souls, at the center of which the Beloved himself dwells", she writes in The Interior Castle. ${ }^{63}$ Our journey here ascends from the first castle where we battle base instinct, to higher levels that represent the heart beginning to fill with love and empathy for others, to the seventh and highest castle, representing the brain, into which transcendence transports us to the realm of knowing and uniting with God.

The altered state of consciousness reached in numinosity was once thought to be experienced only by mystics and saints such as Teresa, who were often dismissed as fanatics or delusional, but Arthur Newberg believes the brain is actually altered when a subject focuses on a religious idea or thought, and numinosity, with practice, is attainable by all healthy brains. Newberg began his numinosity experiments on Tibetan Buddhist monks as they meditated and Catholic nuns as they performed a centering prayer dating to the $14^{\text {th }}$ Century text, The Cloud of Unknowing. Results were recorded using an imaging technique called single photon emission computed tomography, which measures blood flow to the brain. ${ }^{64} \mathrm{He}$ found that activity in the frontal lobes increased for his participants, especially just above the eyes in the prefrontal cortex, which plays a vital role in processing language, memories, self-reflective consciousness, complex social functions, pleasure, and religious activities. ${ }^{65} \mathrm{He}$ notes that the parietal lobes, which help us orient toward where we are in the physical world, is slowed in meditation and prayer, leaving the practitioner feeling a sense of timelessness and infinite space. "In this way, we can demonstrate that transcendent, mystical, and spiritual experiences have a real biological component. Furthermore, the neurological changes that occur during meditation disrupt the normal processes of the brainperceptually, emotionally, and linguistically-in ways that make the experience indescribable, awe-inspiring, unifying, and indelibly real. In fact, the intensity of such experiences often gives the practitioner a sense that a different or higher level of reality exists beyond our everyday perceptions of the world". ${ }^{66}$ Although these experiences are most often interpreted in the context of religious beliefs, nonreligious practitioners have found secular meaning in them, such as the feeling of being connected to the universe, to nature, and to all that ever was.

Newberg explains that in prayer, the sense of God becomes physiologically real for the nuns, as does the sense of inner peace for the monks. And this is due to another important brain structure, the thalamus, which regulates sensory perception as it enters the prefrontal cortex, and which becomes more active during meditation and prayer. Although perceptions are altered, the thalamus continues to work to make them lucid by communicating a sense of reality about them to the prefrontal cortex. True to one's belief system, the experience is interpreted by the nun, monk, or secular practitioner as real; transcendent, peaceful, and in the presence of God.

Our emotions are also tied to neurobiological activity in the brain. Enjoyable experiences cause the pleasure neurotransmitter dopamine to be released into the system, just as various stress hormones are released when we find ourselves in an anxious situation, which triggers fight or flight emotional cues. Thus, by meditating on something we believe to be pleasant, the amygdala and other parts of the limbic system signal our brains that an experience is emotionally powerful, causing us to accept it as real. ${ }^{67}$ We seek these pleasant and rewarding experiences because dopamine, and the nucleus accumbens, together reinforce the motivation to seek them. ${ }^{68}$

\section{Is There a Future for Religion?}

Our Paleolithic ancestors almost 200,000 years ago were foragers who probably thought of themselves as an element of nature, possessing spirits that would be reincarnated into other animals or plants, all of which comprised a rudimentary spiritual belief system. Cave 
paintings depicting the spirits, as well as daily life, date to as early as 70,000 years BP. ${ }^{69}$ French sociologist Émile Durkheim tells us that these early spirits were thought of as benefactors. He says, "Of course they punish a man if he does not treat them in a fitting manner, but it is not their function to work evil." This simple belief system was the foundation of later, more complicated and diverse religious institutions, including the idea that the polytheistic spirits resemble the benevolent God of later monotheistic religions. Durkheim also tells us that despite the differences in doctrine and dogma, all religions serve the same purpose, and all are real and true belief systems for those who adhere to the doctrines and rituals of the various denominations. "All religions answer, though in different ways, to the given conditions of human existence," Durkheim says. ${ }^{70}$

Civilization's move from small foraging bands to agrarian societies, marks the beginning of a power hierarchy between men and women, established because farm families needed the labor of many children, whose care was relegated to women at home, while men tended to political and economic activity in public centers as populations grew. Uruk, nestled between the Tigris and Euphrates rivers, is recognized as humankind's first city, established about 3600 BCE in the first state of Sumer (southern Mesopotamia). Archaeologists excavated two ceremonial centers in Uruk, theorizing that they were temples. "The smaller one, called the White Temple, in time became associated with the sky god, An, the father of all gods, representing patriarchal authority," another precursor to modern monotheism, writes David Christian et al. As other Mesopotamian cities were established, special temples were erected to attract and care for special gods that would protect residents and grant them prosperity. Additional hierarchies were established; including the possibility that priests oversaw construction of the temples with which they were associated, as well as overseeing sacrifices to the gods, and in relaying fantastical celestial stories to the lower classes. "Religious, political, economic, and even military power may, for a brief time, have been in the hands of the priests," Christian explains. ${ }^{71}$ Astrophysicist Eric Chaisson qualifies Christian's statement by explaining the 'brief time' that priests dominated a largely illiterate public was for several thousand years, and included surrounding ancestors of the ancient Greeks, Romans, Celts, Germans, and Slavs, who believed that the gods of Sumer ruled the world through the priestly class. "Apparently myths become truths if upheld long enough," he says. ${ }^{72}$ These gods are believed to have created the me, "a Sumerian term for the institutions, forms of social behavior, emotions, and sign of office, which as a whole were seen as indispensable for the smooth operation of the world." ${ }^{73}$ Religion and politics thus found solace in each other, with religion promoting social cohesion, including with its legitimization of a state's leaders, who in turn promoted the chosen belief system as the state religion. Durkheim reinforces this idea when he says that religion is something eminently social. "Religious representations are collective representations which express collective realities; the rites are a manner of acting which take rise in the midst of the assembled groups, and which are destined to excite, maintain or recreate certain mental states in these groups. ${ }^{34}$ The same could be said of politics, showing us that historically, religion and politics were not strange bedfellows, which led for many centuries to power struggles, religious persecution and wars, such as the Crusades, and to genocide such as in Nazism, persisting today in predominantly Islamic countries where the two institutions are still inextricably entwined..$^{75}$

The schism that developed between religion and science gained its foothold during the Renaissance, although the experimental test and empirical evidence were used as early as ancient Greece. A falling away from institutional religion began during the $18^{\text {th }}$ Century Enlightenment period when human reason soundly questioned religious doctrine that was flying in its face, fueled further a century later in 1859 with the publication of Charles Darwin's The Origin of Species, which refutes conclusively the origin stories 
that had been put forth by institutional religion. Sigmund Freud in the early $20^{\text {th }}$ Century calls the psychological nature of religious doctrines 'illusions' in that "they are derived from human wishes" for a father's protection from nature's brutality, and for the promise of reward after death, (Freud primarily refers to Judeo-Christian doctrine).$^{76} \mathrm{He}$ attributes religion's loss of influence on people to the scientific spirit. "The greater the number of men to whom the treasures of knowledge become accessible, the more widespread is the falling-away from religious belief," he says. And in just the past six decades, statistics show an even more dramatic seismic generational shift in religious commitment. In an analysis published in the journal PlosOne in 2015, the authors review answers given by 11.2 million respondents to four nationally distributed questionnaires about religious beliefs, which have been conducted since 1966. After comparing people of different generations at identical ages, the analysis concludes that millennials are the least religious generation in American history $\mathrm{y}^{77}$ following the cultural trend established in Western Europe earlier in the $20^{\text {th }}$ Century. The theory is that modern western culture prizes individualism, and religious affiliation prizes the group, dominated by an authoritarian male, whom we need for moral guidance and whom we obey out of fear of reprisal in a next life if we do not.

As we discussed earlier, morality predates religion by countless millennia. In an explanation from Plato's Euthyphro, Socrates philosophizes that we would be free to appeal directly to the good reasons the gods might give us for deeming acts moral, and if we determine that the reasons are not good, we need not follow their dictates. "After all, thoughtful people can give reasons why they don't kill, rape, or torture other than fear of eternal hellfire, and they would not suddenly become rapists and contract killers if they had reason to believe that God's back was turned, or he told them it was OK," writes psychologist Steven Pinker. And in the Old Testament, God surely tells the Israelites to commit mass rape and genocide, while smiting to death blasphemers, homosexuals, adulterers, and those who toiled on the Sabbath. ${ }^{78}$

Our conundrum is to find something we have lost in religion, some meaning that transcends a hostile universe, where we are each but specks of matter whose time spent on a nondescript planet registers only infinitesimally on the cosmos's 13.8 billion-year-old timeline. Freud believes that "the relationship between civilization and religion must undergo a fundamental revision. By withdrawing their expectations from the other world and concentrating all their liberated energies into their life on earth, (people) will probably succeed in achieving a state of things in which life will become tolerable for everyone and civilization no longer oppressive to anyone." As the $19^{\text {th }}$ Century German poet Heinrich Heine wrote in Deutschland, "We leave Heaven to the angels and the sparrows."79

What should the future of religion look like? Perhaps a combogenesis, to borrow from biologist Tyler Volk, in which a combination and integration of previously existing things form something innovative. ${ }^{80}$ Something like Albert Einstein's cosmic religion, whose impersonal God is heavily influenced by the $17^{\text {th }}$ Century philosopher Benedict De Spinoza. Combined perhaps with thoughts of numinosity discussed earlier and from the Indian mystic and 1913 Nobel Laureate Rabindranath Tagore, who in The Religion of Man spoke of the many times "music and the glow of a sunset have brought to our hearts the pulsation of the limitless world." ${ }^{11}$ Tempered with Andrew Newberg's ideas that our paths to our gods snake through our brains, and reality is what each of us perceives it to be in our minds. Something for everyone. . And in concert with William Grassie's hermeneutical approach, in which all religions contain elements of truth, and all perspectives, including science, can be adopted and woven into our human story, an intellectual non-violence in which God-bywhatever-name is "the set of all phenomena-past, present, future-as well as that which may also in some sense precede and transcend this universe." 82 All of our stories, all of us, contribute to the narrative of religion's future. 
Einstein's cosmic religion does not recognize dogma, nor a God made in man's image, but it is accepting of all denominations that do. And millions of faithful people with open minds subscribe to innumerable forms of religion; it is not religion that is the enemy. "The true enemy is the substitution of thought, reflection, and curiosity with dogma," Frans De Waal writes.$^{83}$ Cosmic religion is not religion based on fear of punishment, nor does it claim to have received unbending moral law from a divine source. Moral law should aid humans by responding to their changing societal needs rather than hinder humans because it is incontrovertible. Einstein writes, "The ethical behavior of man is better based on sympathy, education, and social relationships, and requires no support from religion." Cosmic religion is humanistic and encouraging. "The individual feels the vanity of human desires and aims, and the nobility and marvelous order which are revealed in nature and in the world of thought. He seeks to experience the totality of existence as a unity full of significance." ${ }^{84} \mathrm{We}$ are thus unapologetic for being human, and we are, with all animals, plants and inert matter, bound as one to the universe.

Einstein never wavered in his respect for others' sincere religious convictions, a tolerance that has been lacking in institutional religious beliefs both historically and today, although it surely would be part of cosmic religion. Einstein's acceptance of others' myriad religious views was expressed in a letter he wrote in 1929, "We followers of Spinoza see our God in the wonderful order and lawfulness of all that exists and, in its soul, as it reveals itself in man and animal." (Thus establishing our connection to all living things, including De Waal's bonobos.) "It is a different question whether belief in a personal God should be contested. I myself would never engage in such a task. For such a belief seems to me preferable to the lack of any transcendental outlook of life, and I wonder whether one can ever successfully render to the majority of mankind a more sublime means in order to satisfy its metaphysical needs." ${ }^{85}$

Mircea Eliade adds that the cosmos is a living, sacred thing, and cosmic religious experience can be as simple as observing the sky, with its transcendent power to evoke eternity. "The transcendental category of height, of the super terrestrial, of the infinite, is revealed to the whole man, to his intelligence and his soul." 86

\section{Conclusion}

Buddha often said that humans interpret reality in many ways, and there is no one definitive truth. So, it is unlikely that a single religious belief system will ever be adopted by all people, in part because religious beliefs are culturally and biologically ingrained in us and cannot be proven scientifically to the satisfaction of all. Our quest to know the answers to existential questions is much like trying to know the sun, which is partially revealed when its rays pierce the clouds to warm us. But we can never stare at its face, for it would blind us. We are left to continue to use our complex brain with its highly advanced frontal cortex, and our more elusive rational mind, the consciousness that can be thought of as our psyche or soul, to contemplate the divine and to make sense of this world, as it is the only objectively real one. Indeed, French philosopher Baron D'Hobach describes the brain as integrally related to the soul. He writes, "It is by the aid of this interior organ that all those operations are performed which are attributed to the soul." ${ }^{87}$ The key to truth is perseverance, tolerance and respect for all life and for the journeys and realities conjured in the minds of others as our brains tune out profane sensory perceptions and concentrate on the sacred forces we seek. Time and space are suspended and our sense of ourselves fades as the release of dopamine contributes to our numinous and peaceful feelings. Newberg says, "Voila! A new sense of reality-i.e., truth-awakens in our frontal lobes." ${ }^{88}$

\section{Epilogue}

Gracing the ceiling and walls of the Sistine Chapel are Michelangelo di Lodovico Buonarroti Simoni's early $16^{\text {th }}$ Century paintings, including 'Creation of 
Adam,' 'The Separation of Light from Darkness', and 'Last Judgment,' all poignant frescoes portraying an anthropomorphized God. Michelangelo, once a devout Catholic, turned to spiritualism later in life, costing him his pension when Pope Paul IV accused him of blasphemy for suggesting in the 'Last Judgment' that one's direct path to God need not involve institutional religion. Michelangelo's hidden message in the other paintings may have inspired something Spinoza wrote more than a century later: "For both reason and the beliefs of the prophets and Apostles evidently proclaim that God's eternal word and covenant and true religion are divinely inscribed upon the hearts of men, that is, upon the human mind." 89 Thus, intelligent inquiry, made possible by the brain, is the true path to one's God or gods. Centuries before neurobiologist Andrew Newberg tells us that God and religion reside in the brain, and noted psychologists tell us how they are a function of the mind, Michelangelo shows us. In 'Creation of Adam, God, surrounded by humans, is encased in an anatomically accurate human brain, and in 'The Separation of Light from Darkness', one can see in God's throat a perfect replica of the human spinal cord and brain stem, with intact frontal lobes, the cerebrum, the basilar artery, the pituitary gland and the optic chiasm, ${ }^{90}$ in what can be explained as a metaphysical colligation of God and our brain..$^{91}$ Michelangelo knew.
(4) From

Michelangelo's The Separation of Light from Darkness.

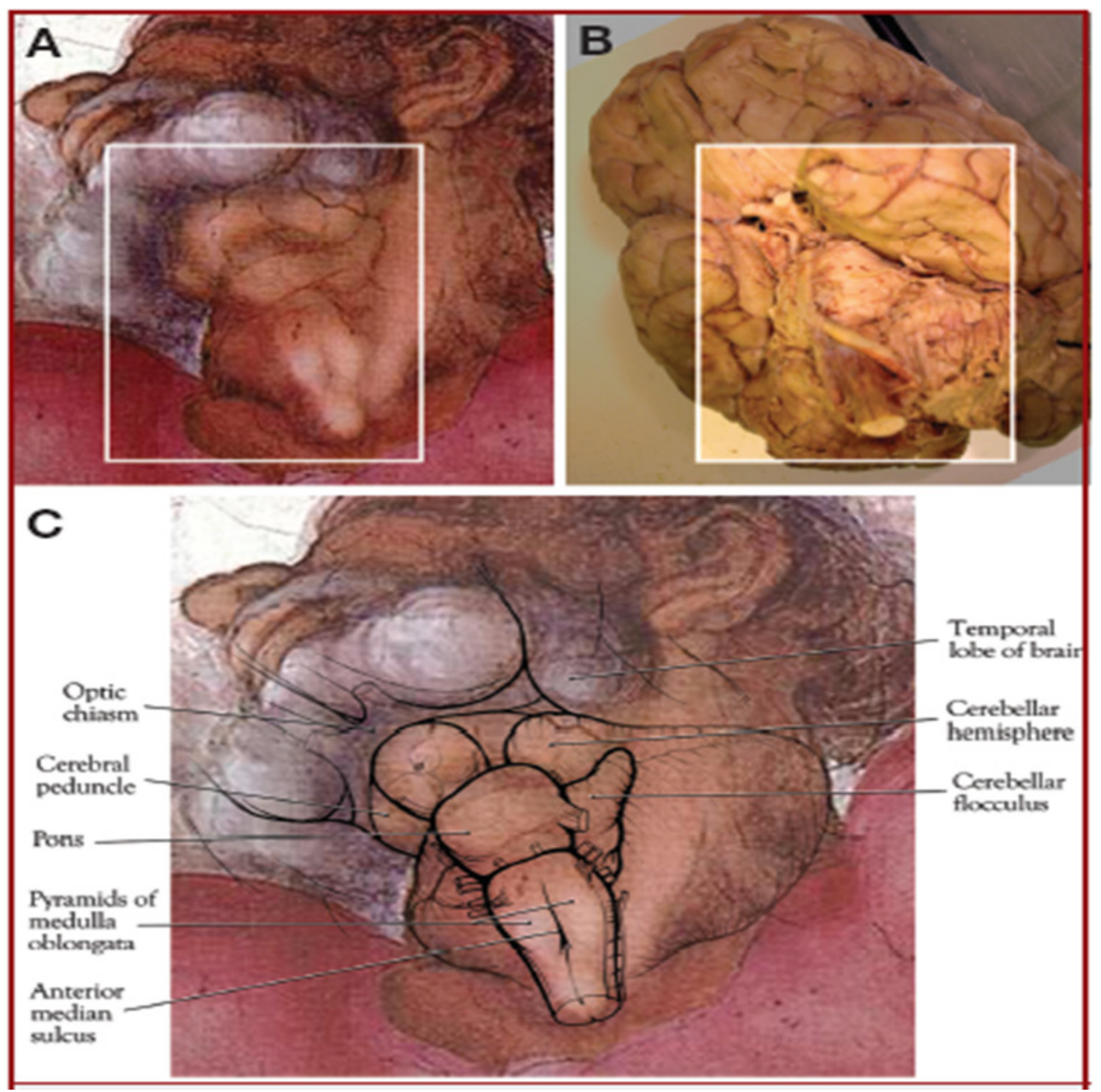




\section{Endnotes}

1 Edwards, Owen "The Skeletons of Shanidar Cave," in Smithsonian, March 2010. Retrieved October 11, 2018 at https:// www.smithsonianmag.com/arts-culture/the-skeletons-ofshanidar-cave-7028477/.

2 De Waal, Frans, The Bonobo and the Atheist, Norton, New York, p. 56, 2013.

3 Newberg, Andrew, Why God Won't Go Away, Ballantine, New York, p. 54, 2001.

4 Joseph, R. The Transmitter to God: The Limbic System, the Soul, and Spirituality, University Press California, San Jose, 2000.

5 D'Aquli, E.G.; Laughlin, Jr., C; McManus, J., The Spectrum of Ritual: A Biogenetic Structural Analysis, Columbia University Press, New York, 1979.

6 Pinker, Steven, How the Mind Works, Norton and Co., New York, p. 556, 1997.

7 Spier, Fred, Big History and the Future of Humanity, John Wiley \& Sons, Ltd, Chichester, UK, p. 181, 2015.

8 Newberg, Andrew, Why God Won't Go Away, Ballantine, New York, p. 19, 2001.

9 Walker, Stephen, Animal Thought, Routledge \& Kegan Paul, London, 1985.

$10 \quad$ Ibid Note 7.

11 Grassie, William, The New Sciences of Religion, Palgrave McMillian, New York, p. 95, 2010.

12 Newberg, Andrew, Why God Won't Go Away, Ballantine, New York, pgs. 16-17, 2001.

13 Laughlin, Jr., C; McManus, J.; and d'Aquli, E.G., Brain, Symbol, and Experience, Columbia University Press, New York, 1992.

14 Pinker, Steven, How the Mind Works, Norton and Co., New York, p. 21, 1997.

15 Grassie, William, The New Sciences of Religion, Palgrave McMillan, New York, p. 19, 2010.

16 Tilllich, Paul, Systematic Theology, Volume 3, University of Chicago Press, Chicago, p. 248.

17 Newberg, Andrew, Why God Won't Go Away,
Ballantine, New York, p. 35, 2001.

18 Maslow, Abraham, Religions, Values, and Peak Experiences, Penguin Books, New York, p. 20, 1970.

19 James, William, The Varieties of Religious Experience, Collins, Glasgow, p. 141, 1960.

20 Peters, Ted, God in Cosmic History, Anselm Academic, Winona Minn., p. 58, 2017.

21 Margolis, Lynn, Sagan, Dorion, Microcosmos: Four Billion Years of Microbial Evolution, Berkeley, University of California Press, pgs. 28-29, 1986.

22 Christian, David, Stokes Brown, Cynthia, Benjamin, Craig, Big History: Between Nothing and Everything, McGrawHill, New York, pgs. 85-87, 2014.

23 Lorenz, Konrad, On Aggression, Methuen, London, pgs. 219-221, 1966.

24 De Waal, Frans, The Bonobo and the Atheist, Norton, New York, pgs. 80-81, 2013.

25 Freud, Sigmund, Totem and Taboo, Random House, New York, pgs. 183-189, 1946.

26 Boehm, Christopher, Hierarchy in the Forest, Harvard University Press, Cambridge MA, 1999.

27 Peters, Ted, God in Cosmic History, Anselm Academic, Winona Minn., pgs. 174-178, 2017.

28 Ibid

29 Bellah, Robert, Religion in Human Evolution, Belknap Press of Harvard University Press, Cambridge, pgs. 244-245, 2011

30 Watsford, the Rev. John, "Wesleyan Missionary Notices," extract of a letter dated October 6th, 1846, Sept. 1847 edition.

31 Newberg, M.D., Andrew, Why We Believe What We Believe, Free Press, New York, p. 133, 2006.

32 Boehm, Christopher, Moral Origins, Basic Books, pgs. 194-195, 101, New York, 2012.

33 Maslow, Abraham, Religions, Values, and PeakExperiences, Penguin, New York, pgs. xiii-xiv, 1970.

34 Hrdy, Sarah, Mothers and Others: The Evolutionary Origins of Mutual Understanding, Belknap Press, Cambridge, 2009. 
35 Darwin, Charles, The Descent of Man, Princeton University Press, Princeton, NJ, pgs. 71-72, 1982 (1871).

36 Boehm, Christopher, "Evolution and Ethics: Human Morality" in Biological and Religious Perspective, Clayton, P. and Schloss, J., Eds., Eerdmans, New York, 2004.

37 Maslow, Abraham, Future Visions, The Unpublished Papers of Abraham Maslow, Sage Publications Ltd., London, pgs. 112-113, 1996.

38 Grassie, William, The New Sciences of Religion, Palgrave McMillan, New York, p. 85, 2010.

39 Pinker, Steven, Enlightenment Now: A Case for Reason, Science, Humanism, and Progress, Viking Press, New York, pgs. 23-24, 2018.

40 Peters, Ted, God in Cosmic History, Anselm Academic, Winona Minn., p. 131, 2017.

41 Jung, Carl, The Practice of Psychotherapy, Routledge, London, p. 364, 1954.

42 Nasr, Seyyed, Religion and the Order of Nature, Oxford University Press, Oxford, p. 7, 1996.

43 Midgley, Mary, Evolution as a Religion, Routledge, London, 2002.

44 Otto, Rudolph, The Idea of the Holy, Oxford University Press, London, 1923, pgs. 12-28.

45 Ibid

46 Jung, Carl, Psychology \& Religion, Yale University Press, New Haven, pgs. 4-6, 1938.

47 Grassie, William, The New Sciences of Religion, Palgrave McMillan, New York, p. 109, 2010.

48 Jung, Carl, Psychology \& Religion, Yale University Press, New Haven, pgs. 74-75, 1938.

49 Jung, Carl, Psychological Factors Determining Human Behavior, Harvard Tercentenary Publications, Cambridge, 1936.

50 Freud, Sigmund, Civilization and Its Discontents, Norton, New York, pgs. 24-29, 55, 69, 2010.

$51 \quad$ Ibid

52 Fuller, Andrew R., Psychology and Religion, Rowman and Littlefield, London, p. 67, 1994.

53 Maslow, Abraham, Religions, Values, and Peak-
Experiences, Penguin Books, New York, pgs. 18-20, 1970.

54 Warmouth, A. "A Note on the Peak Experience as a Personal Myth," in the Journal of Humanistic Psychology, V, pgs. 18-21, 1965.

55 Newberg, Andrew, Why God Won't Go Away, Ballantine, New York, pgs. 58-63, 80-81, 2001.

56 Shermer, M., How We Believe: The Search for God in an Age of Science, Freeman \& Co., 2000.

57 D'Aquili, E.G. and Newberg, A.B., The Mystical Mind: Probing the Biology of Religious Experience, Fortress Press, 1999.

58 Jung, Carl, The Practice of Psychotherapy, Routledge, London, p. 364, 1954.

59 Jung, Carl, Psyche and Symbol, Doubleday, New York, 1958.

60 Burns, T., and Laughlin, C.D. "Ritual and Social Power” in The Spectrum of Ritual, eds. D'Aquili, Laughlin, and McManus, Columbia University Press, New York, 1979.

61 Smith, W.J., "Ritual and the Ethology of Communicating” in The Spectrum of Ritual, eds. D'Aquili, Laughlin, and McManus, Columbia University Press, New York, 1979.

62 Jung, Carl, Modern Man in Search of a Soul, Harcourt, Brace, and World, New York, pgs. 224-225, 1933.

63 Teresa of Avila translated by Mirabai Starr, The Interior Castle, Riverhead Books, pgs. 21-23 2003.

64 Newberg, M.D., Andrew, Why We Believe What We Believe, Free Press, New York, pgs. 170-184, 2006.

65 Muramoto, Osamu “The Role of the Medial Prefrontal Cortex in Human Religious Activity," in Medical Hypotheses, Vol. 62 pgs. 479-485, 2004.

66 Newberg, M.D., Andrew, Why We Believe What We Believe, Free Press, New York, pgs. 169-170, 2006.

67 Saver, J.L. and Rabin, J. “The Neural Substrates of Religious Experience" in the Journal of Neuropsychiatry and Clinical Neuroscience, Vol. 9, pgs. 498-510, 1997.

68 Gray, J.A. “A Critique of Eysenck's Theory of Personality" in A Model for Personality, Springer-Verlag, New York, pgs. 246-276, 1981.

69 Christian, David; Brown, Cynthia; Benjamin, Craig; Big History: Between Nothing and Everything, McGraw-Hill, New 
York, pgs. 97-98, 130-133, 2014.

70 Durkheim, Emile, The Elementary Forms of the Religious Life, translated by Joseph Swain, CreateSpace Independent Publishing Platform, pgs. 111, 1, 5, 2014.

71 Ibid, Note 65.

72 Chaisson, Eric, Epic of Evolution: Seven Ages of the Cosmos, Columbia University Press, New York, pgs. 418-419.

73 Ibid, Note 65.

74 Ibid, Note 68.

75 Pinker, Steven, Enlightenment Now: The Case for Reason, Science, Humanism, and Progress, Viking, New York, pgs. 428-430, 2018.

76 Freud, Sigmund, The Future of an Illusion, trans. by James Strachey, Norton \& Co., New York, pgs. 38, 50-51, 1961.

77 Twenge, Jean, “The Real Reason Religion is Declining in America," in Psychology Today retrieved online at https://www.psychologytoday.com/us/blog/our-changingculture/201505/the-real-reason-religion-is-declining-inamerica, December 1, 2018.

$78 \quad$ Ibid Note 71.

79 Ibid Note 72

80 Volk, Tyler, Quarks to Culture, Columbia University Press, New York, pgs. 204, 211, 2017.

81 Tagore, R. The Religion of Man, George Allen \& Unwin, London, 1932.

82 Grassie, William, The New Sciences of Religion, Palgrave McMillan, New York, pgs. 181-183, 2010.

83 De Waal, Frans, The Bonobo and the Atheist, Norton, New York, p. 109, 2013

84 Einstein, Albert, On Cosmic Religion and Other Opinions and Aphorisms, Dover, New York, pgs. 48-52, 2009.

85 Einstein, Albert, in a letter to E. Busching, quoted in Einstein and Religion, Jammer, Max, Princeton University Press, Princeton, NJ, p. 51, 1999.

86 Eliade, Mircea, The Sacred and the Profane: The Nature of Religion, Harcourt, New York, pgs. 116-119, 1959.

87 D'Holbach, Baron, The System of Nature Vol. One, Clinamen Press, Manchester, p. 73, 1999.
88 Newberg, M.D., Andrew, Why We Believe What We Believe, Free Press, New York, p. 187, 2006.

89 De Spinoza, Benedict, Theological-Political Treatise, Cambridge University Press, Cambridge, UK, p. 163, 2007.

90 Suk, Ian, and Tamargo, Rafael, from "Concealed Neuroanatomy in Michelangelo's Separation of Light from Darkness in the Sistine Chapel," in Neurosurgery, Vol. 66, No. 5, pp. 851-861.

91 Fields, R. Douglas, "Michelangelo’s Secret Message in the Sistine Chapel: A Juxtaposition of God and the Human Brain," Scientific American, May 27, 2010. Retrieved December 4, 2018 at https://blogs.scientificamerican.com/guest-blog/ michelangelos-secret-message-in-the-sistine-chapel-ajuxtaposition-of-god-and-the-human-brain/. 